Volume 12

Issue 3 Justice and the Prevention of Genocide

Article 20

$12-2018$

\title{
Book Review: The Broken Voice
}

Linda J. Burghardt

Scholar-in-Residence, Holocaust Memorial \& Tolerance Center of Nassau County NY

Follow this and additional works at: https://digitalcommons.usf.edu/gsp

\section{Recommended Citation}

Burghardt, Linda J. (2018) "Book Review: The Broken Voice," Genocide Studies and Prevention: An

International Journal: Vol. 12: Iss. 3: 190-192.

DOI:

https://doi.org/10.5038/1911-9933.12.3.1634

Available at: https://digitalcommons.usf.edu/gsp/vol12/iss3/20

This Book Review is brought to you for free and open access by the Open Access Journals at Digital Commons @ University of South Florida. It has been accepted for inclusion in Genocide Studies and Prevention: An International Journal by an authorized editor of Digital Commons @ University of South Florida. For more information, please contact digitalcommons@usf.edu. 
Book Review: The Broken Voice

\author{
Linda J. Burghardt \\ Holocaust Memorial \& Tolerance Center of Nassau County, NY \\ Nassau County, NY, USA
}

The Broken Voice: Reading Post-Holocaust Literature

Robert Eaglestone

Oxford University Press, Oxford, England, 2017

208 Pages; Price: $\$ 65.00$ Hardcover

Reviewed by Linda F. Burghardt

Scholar-in-Residence, Holocaust Memorial \& Tolerance Center, Nassau County, New York

How is it that the Holocaust, which ended more than seven decades ago, still remains such a powerful force in our culture? What exactly is its legacy? Why is it that Holocaust memory still speaks to us in such stirring tones? And what, for those of us listening intently as these questions are posed in this bright new book, is the "broken voice?" Before we are invited to delve deeply into an understanding of Robert Eaglestone's concepts about the powers of narrative-powers which he believes are capable of providing the answers - the author offers a story for us to ponder.

The tale begins with Imre Kertész, a Jewish Holocaust survivor from Hungary who became a highly acclaimed novelist and a translator of works of philosophy into Hungarian. In 2002, he won the Nobel Prize for Literature, the first Hungarian to do so, "for writing that upholds the fragile experience of the individual against the barbaric arbitrariness of history," according to the judges. His novels deal with genocide, dictatorship and personal freedom, subjects with which he was deeply familiar, as he himself was deported to Auschwitz at the age of 14 and spent years at Buchenwald. In his Nobel Laureate acceptance speech, Kertész asked the provocative question, "Which writer today is not a writer of the Holocaust?" He explained that works do not have to specifically focus on the Holocaust for readers to sense what he called the "broken voice" in modern European art, a voice that he said has been dominant in contemporary literature for decades.

Eaglestone, of course, tells us this story for a reason. And once it is done, he states that the goal of his new and insightful book is "To attend to this 'broken voice' in literature in order to think about the meaning of the Holocaust in the contemporary world." His aim is to examine how the concepts of meaning are inserted in literature about the Holocaust and genocide, and he succeeds masterfully. Using a compact, six-part format, Eaglestone begins by explaining how literature can shed more light on the Holocaust than history can. To elaborate, he extensively cites Hannah Arendt, the Jewish, German-born, American philosopher and political theorist who is well known for her comments on totalitarianism, the nature of power and evil and the way in which ordinary people become unwitting actors in totalitarian systems. One of Arendt's most salient statements is that "storytelling reveals meaning without committing the error of defining it," and Eaglestone fully accepts this and builds on her distinction between meaning and truth. He posits that meaning is derived from reason and from speech, and that if evidence is employed to bring facts from the past into focus with historical events, then we are likely to understand that past by first acknowledging that it is shaped by meaning based on how the evidence is used.

Thinking and facts are, of course, inexorably joined, and Eaglestone forcefully agrees with Arendt that fiction and memoir, both of which he defines as forms of storytelling, offer meaning by providing shape. He also describes in depth his belief in the primacy of literature over history as a most powerful tool for understanding the past, going so far as to suggest that it is engagement with memory that provides meaning to us and is a fundamental way of understanding our basic human nature. Regarding the Holocaust specifically, Eaglestone argues that although a great deal has been written about the events themselves, and they have been presented in various forms of theater and visual art, he believes there is a virtual canyon between what the public understands to have happened and how the scholars and historians describe the facts that took place and the concepts that drove the events forward. He believes that our culture and society require new ways to analyze what happened in order for concepts of thinking about genocide to evolve.

Linda J. Burghardt. "Book Review: The Broken Voice." Genocide Studies and Prevention 12, 3 (2018): 190-192. @2018 Genocide Studies and Prevention.

https://doi.org/10.5038/1911-9933.12.3.1634 
This short but cogent book is divided into sections that offer five new methods of listening to the "broken voice" in order to create new ways to hear it clearly and understand its thrust. Each chapter is insightful on its own yet also presents material that is further illuminated by the ideas the author develops in the others. Overall the contextual cross-references help us understand not only the parts of the argument but the greater whole they form when taken together. The tone of the book is scholarly yet accessible, generously enhanced with quotes from philosophers, historians, and literary figures in ways that add weight and gravitas to the already deeply explicated theses. Footnotes throughout add to the story, and a well-documented index efficiently points the reader toward the desired subject matter. Eaglestone, as a literature professor, is fully enmeshed in his subject matter, telling us in no uncertain terms that "the past is too important to be left solely to historians."

Reviewed to critical acclaim in journals of philosophy, the book is highly recommended for upper-level undergraduates, graduate students and faculty, particularly those who have an interest in the relationship between ethics and genocide. It would also be of interest to lay persons with a grounding in philosophy who want to undertake a study of the interrelationships among literature, history, truth, meaning and thought, and to those who seek a deeper understanding of these different forms of knowledge.

Philosophical thinkers will find a great deal to learn about epistemology in this slim volume; in addition, they stand to gain critical skills in understanding the nexus of art and culture as related to power and evil. New constructs through which to view and understand the Holocaust can be gained from a thorough reading. Although the book is dense with facts, theories and references, it is focused successfully throughout on bringing the reader through exacting analyses to the logical conclusions briefly stated in the introduction. The book is extremely well researched, and the authors and works cited in the footnotes form an extensive and useful 13-page bibliography of philosophical thinking about the Holocaust in itself. Eaglestone is a British academic, writer, and professor of contemporary literature and thought at Royal Holloway, University of London, in the Department of English. His writings all tend to cluster around critical issues of contemporary literature and literary theory, contemporary philosophy, Holocaust and genocide studies and the legacy of the Holocaust and the Second World War.

Eaglestone is known for his provocative ideations on contemporary fiction and ethics. He is well credentialed to write "The Broken Voice," and says that his research explores how literature "thinks," especially in the way this functions in relation to issues of ethics. By this he means a concern with ethical relationships to the past, centrally the Holocaust, and to other genocides and atrocities as well. In this book he draws on memory studies and trauma studies, as well as on the controversial ideas of original thinkers such as Jacques Derrida, Raymond Williams and Phillipe Lacoue-Labarthe.

Eaglestone's book was written with a deep awareness of the fact that we live in an age of historical revisionism, and he is concerned with the fact that false representations of memory serve to create a fertile climate for right-wing extremists to assault the basic facts of history itself. Given this disturbing situation, Eaglestone discusses the purpose of literature is a means not only to recall what actually happened in the Holocaust, but to help us learn that not all of history can be explained by fact patterns and logic.

It is critical, he argues, to think deeply about events and join the past, present and future together in a way that has meaning. It is only through the constant effort of sifting and shifting our understanding of how the facts fit together with the vagaries of human thought and emotion that we can being to grasp and repair the "broken voice."

Eaglestone deftly takes us through the process one step at a time. In the first chapter, entitled The Public Secret, he helps us gain a subjective understanding of some of the most highly debated themes of the war crimes committed by the Nazis. He does this by asking us to consider how much ordinary Germans knew about the events of the Holocaust. Were they aware of the concentration camps? Did they know about the atrocities that led to the so-called Final Solution? Maintaining that it is beyond the ability of historians to determine the extent of individual knowledge, the author uses examples from novels to examine the structure and extent of complicity and how this functions to efficiently degrade communities. 
Chapter two focuses on evil and raises the issue of how it is to be understood. Here the author uses material by and about the perpetrators of the Holocaust and then turns to contemporary fiction to search for definition and meaning. Hannah Arendt's ideas once again illuminate the discussion. This is the longest chapter in the book, and the one in which the author seeks to define the essential nature of evil, maintaining that much of the evil in the Holocaust was perpetrated not by monsters, as a great number of historians would have us believe, but by ordinary people.

Next the author turns to methods of working through the past to try to come to grips with its influence on today. This is the most complex chapter, and once again he analyses novels to see why and how individuals can come to understand complex events of the past-or fail to do sostressing how memory and meaning invariably meet and shape one another.

Chapters four and five consider the colonial past and post-colonial present and their relationship to the Holocaust and genocide, examining racist ideologies by focusing on African trauma literature. In the final chapter, Eaglestone turns to art and culture to consider whether artistic representations of the Holocaust give it justice or if the act of creating the art cheapens the subject and turns it into something designed to shock, rather than to commemorate or offer meaning. He suggests that the Holocaust is simply too complex to be captured effectively in many art forms.

Ultimately, Eaglestone argues that literature and art must be pondered deeply, discussed among the populace and then recreated and retold in new ways. He says, "The Jewish philosopher and survivor Emmanuel Levinas wrote that the cries of the victims of the Holocaust 'are inextinguishable: they echo and re-echo across eternity. What we must do is listen to the thoughts that they contain."' This, he concludes, provides our best chance of fixing the "broken voice." 